\title{
Key genes in the phenylpropanoids biosynthesis pathway have different expression patterns under various abiotic stresses in the Iranian red and green cultivars of sweet basil (Ocimum basilicum L.)
}

\section{Mojgan Shahivand}

Islamic azad university Arak branch

Reza Mir Drikvand ( $\nabla$ drikvand_r@yahoo.com)

Islamic Azad University Khorramabad Branch https://orcid.org/0000-0001-5702-6779

Masoud Gomarian

Islamic Azad University of Arak

Kamran Samiei

Islamic azad university Kangavar branch

\section{Research Article}

Keywords: Abiotic stress, Gene expression pattern, Ocimum basilicum L., Phenylpropanoids, Sweet basil

Posted Date: February 17th, 2021

DOI: https://doi.org/10.21203/rs.3.rs-205855/v1

License: (c) (i) This work is licensed under a Creative Commons Attribution 4.0 International License.

Read Full License 


\section{Abstract}

Phenylpropanoids are a large and important family of plant secondary metabolites. The biosynthetic pathway of phenylpropanoids is induced in plants under environmental stresses to cope with these harmful conditions. In the present study, for the first time, we identified and characterized one reference gene (ACTIM) and three key biosynthetic genes (4CL, C4H and CVOMT) in the Iranian red and green cultivars of sweet basil. Also, the expression patterns of $4 C L, C 4 H$ and $C V O M T$ biosynthetic genes were determined for the first time in the Iranian red and green cultivars of sweet basil under cold, drought, heat, light and salt stresses. The results showed that the ACTIN, $4 C L, C 4 H$ and $C V O M T$ genes identified in the Iranian cultivars are identical to other cultivars in terms of all characteristics such as ORF length, protein sequence length, molecular weight, functional domains, lack of signal peptide, subcellular localization site, and secondary structures. Our results also revealed that the $4 C L, C 4 H$ and $C V O M T$ biosynthetic genes have different expression in the Iranian red and green cultivars of sweet basil under abiotic stresses and their expression patterns are cultivar-dependent. The findings of this study can advance our knowledge of phenylpropanoids biosynthesis in plants under environmental stresses. These findings also can be used in plant breeding programs for stress tolerance in sweet basil and other plants.

\section{Introduction}

The medicinal plants produce a wide range of valuable therapeutic and industrial secondary metabolites (Saxena et al. 2013; Van Wyk and Wink 2018). Due to advantages such as easy availability, safety and cost-effectiveness, the medicinal plants have been widely used in various industries (Lim 2012; Saxena et al. 2013; Van Wyk and Wink 2018). Among all medicinal plants, the members of genus Ocimum are very valuable for their therapeutic compounds and they contain various secondary metabolites with medicinal properties (Miraj and Kiani 2016; Purushothaman et al. 2018). On the other hand, among 150 species of the genus Ocimum, secondary metabolites of sweet basil (Ocimum basilicum L.) are the most widely used in the pharmaceutical and cosmetics industries and this plant is the major essential oil-producing crop which is cultivated commercially all over the world (Nerio et al. 2010; Bilal et al. 2012; Miraj and Kiani 2016; Purushothaman et al. 2018). Sweet basil is an annual, herbaceous, aromatic medicinal plant of the Lamiaceae family (Khair-ul-Bariyah et al. 2012; Miraj and Kiani 2016).

The sweet basil contains chemical compounds such as terpenes, tannins, flavonoids and phenylpropanoids (Grayer et al. 1996; Bilal et al. 2012). Two phenylpropanoids, methyl eugenol and methyl chavicol, are the most important ingredients in sweet basil essential oil (Simon et al. 1990; Joshi 2014; Tahsili et al. 2012). The phenylpropanoids are produced from phenylalanine and tyrosine through shikimate pathway. Several enzymes are involved in phenylpropanoids biosynthesis from phenylalanine in plants (Herrmann and Weaver 1999; Haslam 2014). The phenylpropanoids biosynthetic pathway in plants begins with phenylalanine, which is then deaminated to cinnamic acid by phenylalanine amonialyase (PAL) enzyme. The PAL enzyme by converting phenylalanine to cinnamic acid plays a vital role in phenylpropanoids biosynthesis in plants (Achnine et al. 2004; Swedan 2013; Khakdan et al. 2018). The second key enzyme in phenylpropanoids biosynthesis, cinnamate 4-hydroxylase $(C 4 H)$, converts 
cinnamic acid to p-coumaric acid (Li et al. 2019). The C4H acts via an enzyme complex and connects phenylpropanoid biosynthetisis to other metabolic processes (Winkel-Shirley 1999; Achnine et al. 2004). A small family of $\mathrm{C} 4 \mathrm{H}$ genes exists in some plant such as Zea mays and Medicago sativa, whereas, other plants such as Brassicanapus, Pisum sativum, Arabidopsis thaliana and Petroselinum crispum contain only one C4H gene (Frank et al. 1996; Koopmann et al. 1999; Chen et al. 2007; Andersen et al. 2008; Xu et al. 2009; Douglas et al. 2011). Over-expression of $C 4 H$ enhanced decursinol angelate level in hairy roots of Angelica gigas (Park et al. 2012). The antisense suppression of $C 4 H$ gene reduced levels of chlorogenic acid, flavonoids and lignins in M. sativa transgenic plants (Reddy et al. 2005). Members of 4coumarate-CoA ligase ( $4 C L$ ) gene family catalyze the conversion of 4-coumaric acid to 4-coumaroyl-CoA and participate in phenylpropanoid biosynthesis in plants (Hu et al. 1998; Hamberger and Hahlbrock 2004; Wang et al. 2016). Members of $4 C L$ gene family are also necessary in production of 4-cinnamic acid CoA esters that are required for the formation of plant products such as lignin, stilbenes and flavonoids (Wang et al. 2016). Over-expression of $4 C L$ gene enhanced flavone level in hairy roots of Scutellariabaicalensis (Kim et al. 2014). On the other hand, down-regulation of $4 C L$ reduced lignin content in transgenic switchgrass (Xu et al. 2011). The chavicol O-methyltransferase (CVOMT) transfers a methyl group from S-adenosylmethionine to chavicol and produces methylchavicol (Gang et al. 2002). The CVOMT has higher expression level in young leaves of basil compared to older leaves (Gang et al. 2002). Different chemotypes the red and green sweet basil contain various phenylpropanoid content and some of them are rich in specific phenylpropanoids (Beatovic et al. 2015; Bilal et al. 2012; Simon et al. 1990).

Previous studies have reported that phenylpropanoids biosynthesis in plants is affected by growth and development, biotic and abiotic stresses (Batard et al. 1997; Solecka 1997; Bellés et al. 2008; Silva et al. 2012; Niinemets et al. 2013; Meek 2015; Deng and Lu 2017; Rastogi et al. 2019). In a study, the insect and mechanical induced stresses enhanced production of phenylpropanoids such as eugenol, eugenol acetate, dillapiole and myristicin in the leaves of Mangiferaindica (Silva et al. 2012). In the other study, the cold, drought, flood and salt stresses changed expression of phenylpropanoids biosynthetic genes and also altered accumulation level of these compounds in Ocimumtenuiflorum (Rastogi et al. 2019). In the similar study, water stress increased expression of genes involved in phenylpropanoids biosynthesis such as PAL, C3H, 4CL in Oryza sativa (Yang et al. 2006; Moura et al. 2010). Similar results were also observed in Citrullus lanatus plant under drought stress (Yoshimura et al. 2008; Moura et al. 2010).

Because of the effect of environmental stresses on expression of phenylpropanoids biosynthetic genes and phenylpropanoid content, the current study was conducted to investigate the expression of three key biosynthetic genes in the Iranian red and green cultivars of sweet basil under five environmental stresses. In the present study, for the first time we evaluated the effect of cold, drought, heat, light and salt stresses on expression of $4 C L, C 4 H$ and $C V O M T$ genes in the Iranian red and green cultivars of sweet basil.

\section{Materials And Methods}

\section{Plant Materials, Stress Treatments and Sampling}


Seeds of the Iranian red and green cultivars of sweet basil were provided from seed and plant improvement institute of Iran. Seeds were surface sterilized by $5 \%(\mathrm{v} / \mathrm{v})$ sodium hypochlorite and sown plastic pots containing sterilized soil mixture ( $40 \%$ clay and $60 \%$ peats). Pots were fed with NPK fertilizer (20:20:20) and kept at $20 / 20^{\circ} \mathrm{C}$ (light/dark) with a photoperiod of $16 / 8 \mathrm{~h}$. The regular irrigation of pots was performed to maintain normal soil moisture level (Chang et al. 2005). Five weeks plants (7-8 leaves plants) were used to stress treatment. For cold stress, plants were kept in $10^{\circ} \mathrm{C}$ for $24 \mathrm{~h}$ and then transferred to $8^{\circ} \mathrm{C}$ for $24 \mathrm{~h}$. For heat stress, pots containing five weeks plants were kept in $30^{\circ} \mathrm{C}$ for $48 \mathrm{~h}$. For drought stress, the field capacity (FC) of pots was determined using the gravimetric approach (Belhassen 1997) and pots containing five weeks plants were kept in 50\% FC for one week. For light stress, pots were transferred to dark and kept them in $16^{\circ} \mathrm{C}$ for $48 \mathrm{~h}$. Finally, for salt stress, pots were irrigated with $100 \mathrm{mM} \mathrm{NaCl}$ for $48 \mathrm{~h}$. The control plants were well irrigated and kept in normal condition $\left(20 / 20^{\circ} \mathrm{C}\right.$ light/dark and photoperiod of $\left.16 / 8 \mathrm{~h}\right)$ until subsequent analyses. Leaves of control and stressed plants were harvested and immediately frozen in liquid N2. Frozen leaf tissues were transferred to $-80^{\circ} \mathrm{C}$ and kept for subsequent analyses.

\section{RNA Isolation and CDNA Synthesis for real-time PCR}

Frozen leaf tissues of control and stressed plants were thoroughly ground in liquid N2 using mortar and pestle. Total RNA was isolated from ground tissues using Yekta Tajhiz Azma RNA isolation kit (Tehran, Iran) according to the manufacturer's instructions. The integrity of isolated total RNA was evaluated using spectrophotometer and agarose gel electrophoresis. Removing of genomic DNA from isolated total RNA was performed using Yekta Tajhiz Azma DNase I kit (Tehran, Iran) according to the manufacturer's instructions. Two micrograms of DNase l-treated total RNA was used for first strand cDNA synthesis. The cDNA was synthesized using Yekta Tajhiz Azma cDNA synthesis kit (Tehran, Iran) according to the manufacturer's instructions. The complete synthesis of first strand of cDNA and DNA removal from total RNA and was confirmed by PCR using specific ACTIN primers (Table 1).

\section{Molecular Cloning of Biosynthetic Genes and Design of Primers}

To identify coding sequences of $O$. basilicum biosynthetic genes, the protein sequences of known ACTIN, $4 C L, C 4 H$, and $C V O M T$ genes were retrieved from the NCBI protein databse. The protein sequences of each gene were separately aligned against the EST library of $O$. basilicum using NCBI tBLASTn tool (Johnson et al. 2008). The resulting ESTs for each gene were separately pooled and assembled in CLC Genomics Workbench 9.0 software (Qiagen, Valencia, USA). The resulting contigs were compared with the GenBank nr/nt database using BLASTn tool and the contigs with similarity to known ACTIN, $4 C L$, $\mathrm{C} 4 \mathrm{H}$, and $\mathrm{CVOMT}$ genes were selected for further analyses. The selected contigs were evaluated for the presence of complete open reading frames (ORFs) of ACTIN, $4 C L, C 4 H$, and CVOMT genes. The complete ORFs of $A C T I N, 4 C L, C 4 H$, and $C V O M T$ genes were used to design primers by Allele ID 6.0 software (Table 1). The complete ORFs of $A C T I N, 4 C L, C 4 H$, and $C V O M T$ genes were amplified by PCR. PCR was performed using gene specific primers and Pfu DNA polymerase (Thermo Fisher Scientific, Lenexa, USA) on cDNA template. The PCR products were tailed using Taq DNA polymerase (SinaClon BioScience, 
Tehran, Iran) and cloned into pTZ57R/T plasmid (Thermo Fisher Scientific, Lenexa, USA). The plasmids containing $A C T I N, 4 C L, C 4 H$, and $C V O M T$ gene fragments were sequenced. The results of sequencing were analyzed in CLC Genomics Workbench 9.0 software (Qiagen, Valencia, USA) and compared to GenBank using BLASTn tool. The specific primers for real-time PCR were designed based on the sequence of identified genes. The complete coding sequences of identified genes were inserted to Allele ID 7.0 software and specific primers were designed (Table 1). The specificity of the designed primers was evaluated by PCR (sweet basil genomic DNA as template) and NCBI Primer BLAST tool.

\section{In silico and phylogenetic analyses}

In silico analyses of identified genes were performed using ORF finder, CDD, Interproscan, Pfam, Expasy ProtParam , CELLO2GO, SignalP, Phyre2, Vector NTI 10.3, and CLC Genomics Workbench 9.0 tools (Gasteiger et al. 2005; McGuffin et al. 2000; Yu et al. 2014; Marchler-Bauer et al. 2014; Finn et al. 2016; Jones et al. 2014; Petersen et al. 2011; Kelley et al. 2015). Multiple sequence alignment (MSA) of protein sequences of $A C T I N, 4 C L, C 4 H$, and CVOMT genes was performed using Vector NTI 10.3.

\section{Gene expression analysis by Real-time PCR}

To minimize sampling and pipetting errors, the cDNAs were diluted in distillated water. Five microliters of the diluted cDNAs (1:10) was used as template in the real-time PCR. Real-time PCR was performed using Yekta Tajhiz Azma SYBR Premix (Tehran, Iran) on a Bio-rad thermocycler. The specificity of the amplifications was evaluated by melting curve analysis and agarose gel electrophoresis. All amplification reactions were performed in three biological and three technical replications. The efficiency, reproducibility and dynamic range of amplification reactions were evaluated using a standard curve. The identified $A C T I N$ gene was used as reference gene. The resulted cycle thresholds $\left(\mathrm{C}_{t}\right)$ of all genes were normalized by the $\mathrm{C}_{\mathrm{t}}$ values of the ACTIN gene. The relative expression of $4 C L, C 4 H$ and $C V O M T$ genes were determined using the $2^{\Delta \Delta C_{t}}$ method (Livak and Schmittgen 2001). The Mean of $C_{t}$ values were calculated across biological and technical replicates. Statistical analysis was performed using MINITAB 14 software. The Tukey's test was used for multiple comparisons of means at $P<0.05$.

\section{Results}

\section{Characterization of the $A C T I N, 4 C L, C 4 H$, and $C V O M T$ genes}

The PCR amplified fragments of ACTIN, $4 C L, C 4 H$, and CVOMT genes and confirmed the results of EST assembly. The gel electrophoresis showed products with size of 1,334, 1,815, 1,214, and $1631 \mathrm{bp}$ for $A C T I N, 4 C L, C 4 H$, and CVOMT genes, respectively. The results of sequencing showed complete ORFs with size of $1,134,1,704,1,071$, and 1,518 bp for $A C T I N, 4 C L, C 4 H$, and $C V O M T$ genes, respectively (Table 2) (Supplementary file). The complete ORFs of $A C T I N, 4 C L, C 4 H$, and $C V O M T$ genes began with ATG as start codon and ended with TAA and TGA as stop codons (Supplementary file). The ACTIN, $4 C L, C 4 H$, and CVOMT genes were completely identical in red and green cultivars. For this reason, only one sequence 
was included in the analyses. The identified ACTIN gene showed $89.07 \%$ identity to Agastache rugosa, $88.27 \%$ identity to Sesamum indicum, $87.92 \%$ identity to Erythranthe lewisii, $88.22 \%$ identity to Leucas cephalotes and $86.64 \%$ identity Erythranthe guttatus. The nucleotide sequence of $4 C L$ gene identified from Iranian cultivars of sweet basil showed $100 \%$ identity to $O$. basilicum, $92.9 \%$ identity to $O$. tenuiflorum, $85.34 \%$ identity to Agastacherugosa, $83.9 \%$ identity to Salviamiltiorrhiza and $81.72 \%$ identity to Scutellariabaicalensis. The nucleotide sequence of $C 4 \mathrm{H}$ gene displayed $100 \%$ identity to $O$. basilicum, $94.66 \%$ identity to 0 . tenuiflorum, $87.94 \%$ identity to S. miltiorrhiza, $86.89 \%$ identity to Mentha spicata and $86.36 \%$ identity to Mentha aquatica. The identified CVOMT gene exhibited $100 \%$ identity to 0 . basilicum, $98.71 \%$ identity to Ocimum americanum, $96.22 \%$ identity to Ocimum africanum, $96.12 \%$ identity to Ocimum kilimandscharicum and $91.67 \%$ identity 0 . tenuiflorum. These results were similar in two Iranian red and green cultivars of sweet basil.

In frame translation of complete ORFs produced proteins with length of 377, 567, 356, 505 and amino acids for ACTIN, 4CL, CVOMT, and C4H genes, respectively (Table 2). The molecular weight of ACTIN, $4 C L, C V O M T$, and $C 4 H$ proteins were computed $41.664,61.12,39.922$, and $58.044 \mathrm{kDa}$ (Table 2).

The signal peptide prediction showed no signal sequence in the structure of $A C T I N, 4 C L, C 4 H$, and CVOMT proteins (Table 3) (Supplementary file). The subcellular localization prediction exhibited that all identified proteins are localized in the cytoplasm (Table 3) (Supplementary file). The secondary structure prediction revealed the presence of alpha helices and beta strands with variable ratios in all identified proteins (Table 3). The search for functional domain showed the presence of NBD_sugar-kinase_HSP70 domain in $A C T I N$, 4-coumarate-CoA ligase domain in $4 C L$, tans-cinnamate 4-monooxygenase domain in $\mathrm{C} 4 \mathrm{H}$, and AdoMet-MTase Dimerization domains in CVOMT structure (Table 3) (Supplementary file).

The protein sequence of $O$. basilicumACTIN exhibited $97-99 \%$ identitiy to its orthologs in other mono- and dicotyledon plant species (Figure 1). The $O$. basilicumACTIN showed the highest and lowest identity with Sesamumindicum (99\%) and Z. mays (67\%), respectively (Figure 1).

The MSA results showed that the 0 . basilicum $4 C L$ has $67-86 \%$ identitiy to its orthologs in other monoand dicotyledon plant species (Figure 2). The 0 . basilicum $4 C L$ gene showed the highest and lowest identity with Sesamumindicum (86\%) and Triticumaestivum (67\%), respectively (Figure 2).

The MSA results showed that the 0 . basilicumC4H has $85-92 \%$ identitiy to its orthologs in other monoand dicotyledon plant species (Figure 3). The 0 . basilicumC4H gene showed the highest and lowest identity with Striga asiatica (92\%) and Sorghum bicolor (85\%), respectively (Figure 3).

The protein sequence of 0 . basilicumCVOMT exhibited $42-60 \%$ identitiy to its orthologs in other monoand dicotyledon plant species (Figure 4). The 0 . basilicumCVOMT showed the highest and lowest identity with Catalpa bungei (60\%) and Asparagusofficinalis (42\%), respectively (Figure 4).

\section{Gene expression analysis}


The results of relative expression of $4 C L, C 4 H$, and $C V O M T$ genes in red and green cultivars of basil under different environmental stresses treatments have been shown in the figures 1,2 and 3. Analysis of variance revealed significant differences in the expression of $4 C L$ gene under different stresses in both red and green cultivars of basil. In the cold, heat and light stresses similar significant changes in expression of $4 C L$ gene were observed in both red and green cultivars (Figure 5). The expression of $4 C L$ gene was significantly altered in green cultivar under drought and salt stresses, while, in the red cultivar, no significant changes were observed in expression of this gene (Figure 5). The expression level of $4 \mathrm{CL}$ gene was significantly decreased under cold, heat and light stresses in both red and green cultivars (Figure 5). In drought and salt stresses, the expression level of $4 C L$ gene was significantly decreased in green cultivar, while, it remained unchanged in the red cultivar (Figure 5). Comparison of means showed that the changes in the expression level of $4 C L$ gene under different stresses were similar in both red and green cultivars except in the red cultivar exposed to salt stress (Figure 5).

The results of analysis of variance showed significant changes in the expression of $\mathrm{C} 4 \mathrm{H}$ gene under different stresses in both red and green cultivars of basil. In the salt and light stresses a similar significant changes in expression of $\mathrm{C} 4 \mathrm{H}$ gene was observed in both red and green cultivars (Figure 6). On the other hand, in the drought and heat stresses a different significant change in expression of $\mathrm{C} 4 \mathrm{H}$ gene was observed in both red and green cultivars (Figure 6). The expression of $\mathrm{C} 4 \mathrm{H}$ gene was significantly altered in red cultivar under cold stress, while, in the green cultivar, no significant changes were observed in expression of this gene (Figure 6). The expression level of $\mathrm{C} 4 \mathrm{H}$ gene was significantly decreased under salt and light stresses in both red and green cultivars (Figure 6).

Analysis of variance showed significant differences in the expression of CVOMT gene under different stresses in both red and green cultivars of basil. The expression of CVOMT gene significantly increased under the drought stress in both red and green cultivars (Figure 7). In the salt stress, the expression of CVOMT gene was significantly decreased in the green cultivar, but it remained unchanged in the red cultivar (Figure 7). In the cold stress, the expression of CVOMT gene was significantly increased in the green cultivar and decreased in the red cultivar (Figure 7). In heat and light stresses, the expression level of CVOMT gene was significantly decreased in both red and green cultivars. This reduction was the same in both cultivars under the light stress, but in heat stress, the green cultivar showed a much greater reduction in the expression of CVOMT gene (Figure 7).

\section{Discussion}

Among all species of the genus Ocimum, secondary metabolites of 0 . basilicum (sweet basil) are the most widely used in the pharmaceutical and cosmetics industries (Nerio et al. 2010; Bilal et al. 2012; Miraj and Kiani 2016; Purushothaman et al. 2018). In the present study, we investigated the effect of abiotic stresses on the expression of $4 C L, C 4 H$, and $C V O M T$ biosynthetic genes in the Iranian red and green cultivars of sweet basil. For this purpose, we first identified and characterized $4 C L, C 4 H$, and CVOMT biosynthetic genes and ACTIN reference gene in the tested cultivars. In the next step, we 
examined the expression of these genes under the cold, drought, heat, light and salt stresses in the leaves of these cultivars.

The ACTIN genes encode the essential multi-functional proteins that found in all eukaryotic organisms. The ACTIN plays important role in many important cellular processes, including cell division, signaling, cytokinesis, cell motility, and organelle movement (Dominguez and Holmes 2011; Gunning et al. 2015). The ACTIN gene has been identified from different plant species. The ACTIN genes identified from the Iranian red and green cultivars of basil did not show any difference with other basil cultivars. Our results showed that the ACTIN genes identified in Iranian cultivars were identical to other cultivars in terms of all characteristics such as ORF length, protein sequence length, molecular weight, functional domains, lack of signal peptide, subcellular localization site, and secondary structures. Due to the optimized structure, the protein sequence of $A C T I N$ has been highly conserved during evolution (Dominguez and Holmes 2011; Gunning et al. 2015).

The $4 C L$ gene catalyzes the conversion of 4-coumaric acid to 4-coumaroyl-CoA and participates in phenylpropanoid biosynthesis in plants (Hu et al. 1998; Hamberger and Hahlbrock 2004; Wang et al. 2016). The $4 C L$ gene has been identified from different plant species. The $4 C L$ genes identified from the Iranian red and green cultivars of basil did not show any difference with other basil cultivars. Our results showed that the $4 C L$ genes identified in Iranian cultivars were identical to other cultivars in terms of all characteristics such as ORF length, protein sequence length, molecular weight, functional domains, lack of signal peptide, subcellular localization site, and secondary structures.

Numerous studies reported that the expression of $4 C L$ gene involved in biosynthesis of phenylpropanoid decreased under abiotic stresses in plants (Lavhale et al. 2018). The expression of $4 C L$ gene decreased under wounding stress in $A$. thaliana (Soltani et al. 2006). The expression of $4 C L$ gene decreased in $O$. basilicum in response to drought stress (Mandoulakani et al. 2017). Our results were consistent with the previous studies. The expression of $4 C L$ gene significantly decreased in green cultivar under cold, drought, heat, light, and salt stresses. The expression of this gene also significantly decreased in the red cultivar under cold, heat and light stresses and it remained unchanged under drought and salinity stresses. In the heat stress, the expression of $4 C L$ gene in green cultivar showed a greater decrease compared to red cultivar. These results indicate that the expression of $4 C L$ gene is not similar in different cultivars of basil and it depends on the cultivar.

The $\mathrm{C} 4 \mathrm{H}$ gene is a key enzyme in phenylpropanoids biosynthesis that catalyzes conversion of cinnamic acid to p-coumaric acid ( $\mathrm{Li}$ et al. 2019). So far, the $C 4 H$ gene have been identified in $Z$. mays, M. sativa, $B$. napus, P. sativum, A. thaliana and P. crispum plants (Frank et al. 1996; Koopmann et al. 1999; Chen et al. 2007; Andersen et al. 2008; Xu et al. 2009; Douglas et al. 2011). Our results demonstrated that the $C 4 H$ genes identified from the Iranian red and green cultivars of basil were identical to other cultivars in terms of all characteristics such as ORF length, protein sequence length, molecular weight, functional domains, lack of signal peptide, subcellular localization site, and secondary structures. These genes did not show any difference with other basil cultivars. 
Several studies have reported that the expression of $\mathrm{C} 4 \mathrm{H}$ gene in plants changes under abiotic stresses (Sharma et al. 2019). The wounding, cold and salt stresses increased the expression of $C 4 H$ gene in the stem tissues of Hibiscuscannabinus L. (Kim et al. 2013). The expression of $\mathrm{C} 4 \mathrm{H}$ gene remained unchanged in the cold-stressed leaf tissues of 0 . basilicum var. keshkeni luvelou (Rezaie et al. 2020). The $\mathrm{C} 4 \mathrm{H}$ gene highly expressed under the wounding and salt stresses in the Carthamustinctorius (Sadeghi et al. 2013). The copper stress increased the expression of $C 4 H$ gene in the Vitis vinifera (Leng et al. 2015). The expression of $\mathrm{C} 4 \mathrm{H}$ gene increased under the drought stress in the Fragariaananassa and Lotus japonicas plants (Perin et al. 2019; García-Calderón et al. 2015). The salt stress increased the expression of $C 4 H$ gene in the $F$. ananassa and Olea europaea plants (Perin et al. 2019; Rossi et al. 2016). The expression of $\mathrm{C} 4 \mathrm{H}$ gene increased under the chilling stress in the Prunuspersica (Wang et al. 2019).

Our results indicated that the expression of $\mathrm{C} 4 \mathrm{H}$ gene show different pattern under the drought, cold, and heat stresses in the red and green cultivars. The expression of $\mathrm{C} 4 \mathrm{H}$ gene significantly increased in green cultivar under the drought stress, while it significantly decreased in red cultivar. In the cold stress, the expression of $\mathrm{C} 4 \mathrm{H}$ gene significantly increased in red cultivar and it remained unchanged in green cultivar. The expression of $\mathrm{C} 4 \mathrm{H}$ gene significantly increased in red cultivar under the heat stress, while it significantly decreased in green cultivar. The salt and light stresses significantly decreased the expression of $\mathrm{C} 4 \mathrm{H}$ gene in red and green cultivars. In the light stress, the expression of $\mathrm{C} 4 \mathrm{H}$ gene in green cultivar showed a greater decrease compared to red cultivar. These results indicate that the expression of $\mathrm{C} 4 \mathrm{H}$ gene is not similar in different cultivars of basil and it depends on the cultivar.

The CVOMT catalyzes the conversion of chavicol to methylchavicol (Gang et al. 2002). The CVOMT genes identified from the Iranian red and green cultivars of basil did not show any difference with other basil cultivars. Our results showed that the CVOMT genes identified in Iranian cultivars were identical to other cultivars in terms of all characteristics such as ORF length, protein sequence length, molecular weight, functional domains, lack of signal peptide, subcellular localization site, and secondary structures.

The previous studies have shown that the expression of CVOMT gene in 0 . basilicum increases under drought stresses (Mandoulakani et al. 2017; Lavhale et al. 2018; Khakdan et al. 2017).

The expression of CVOMT gene significantly decreased in the cold-stressed leaf tissues of 0 . basilicum var. keshkeni luvelou (Rezaie et al. 2020). In case of drought stress, our results were consistent with the previous studies. The expression of CVOMT gene significantly increased under the drought stress in both green and red cultivars. In the cold stress, the expression of CVOMT gene significantly increased in green cultivar, while it significantly decreased in red cultivar. The expression of CVOMT gene significantly decreased under salt stress in green cultivar and it remained unchanged in red cultivar. In the heat stress, the expression of $C V O M T$ gene in green cultivar showed a greater decrease compared to red cultivar. The light stress significantly decreased the expression of CVOMT gene in both red and green cultivars. These results indicate that the expression of CVOMT gene is not similar in different cultivars of basil and it depends on the cultivar. 
The abiotic environmental stresses cause damage to plant processes, including growth and development, metabolism, photosynthesis and nutrition by inducing the production of free radicals (Sharma et al. 2019; Huang et al. 2019). Thus, plants activate protective systems, including radical scavenging processes and antioxidant compounds (such as phenylpropanoids and other phenolic compounds) to cope with stress condition (Jenks and Hasegawa 2005; Pereira 2016; Korkina 2007). Phenolic compounds act as strong radical scavenging agents due to their ability to donate electrons and hydrogen atoms (Huang et al. 2019; Sharma et al. 2019).

Previous studies have reported that different cultivars of a plant species produce different ratios of the phenolic compounds in response to environmental stresses. The different cultivars of $V$. vinifera produced different composition of phenolic compounds under drought stress (Pinasseau et al. 2017). The results of other study indicated that the phenylpropanoids accumulate at different levels in the UVsensitive and UV-resistant cultivars of Vacciniumcorymbosum (Escobar et al. 2017). In the similar study, the water stress had different effects on phenylpropanoids content and on expression of their biosynthetic genes of $O$. basilicum cultivars (Khakdan et al. 2017). In the study of Rossi et al. (2016), the salt-tolerant and salt-sensitive cultivars of $O$. europaea accumulated different levels of phenylpropanoid under salt stress (Rossi et al. 2016).

Different expression pattern of phenylpropanoids biosynthetic genes under environmental stresses in different cultivars of basil can be caused by structural and morphological differences, differences in cell signaling processes, genetic and epigenetic differences. Cultivars with different morphology and structure show different levels of stress resistance and also display different responses to stress. The cell signaling processes are closely related to plant morphology and differences in morphology affect signaling processes. Differences in gene expression regulation, the presence or absence of specific regulatory cis-acting elements in the promoter of biosynthetic genes differences in the number of these elements are the most important genetic differences that may exist among cultivars. Distribution of particular cis-acting elements in the promoter of biosynthetic genes can change the gene expression pattern in different cultivars. Finally, epigenetic differences such as histone modifications and chromatin remodeling are other factors that can cause different responses in cultivars.

\section{Conclusion}

To our knowledge, the current study is the first report of the identification and characterization of three phenylpropanoids biosynthetic genes in the Iranian red and green cultivars of sweet basil. Also in our study, the expression patterns of $4 C L, C 4 H$ and $C V O M T$ biosynthetic genes were determined for the first time in the Iranian red and green cultivars of sweet basil under cold, drought, heat, light and salt stresses. Our results showed that the $4 C L, C 4 H$ and $C V O M T$ genes identified in Iranian cultivars are identical to other cultivars in terms of all characteristics such as ORF length, protein sequence length, molecular weight, functional domains, lack of signal peptide, subcellular localization site, and secondary structures. Our results also revealed that the expression pattern of $4 C L, C 4 H$ and $C V O M T$ biosynthetic genes is cultivar-dependent. However, to better understand the differences among different sweet basil cultivars in 
response to environmental stresses, the transcriptome of cultivars should be evaluated under stress condition.

The findings of the current study can advance our knowledge of phenylpropanoids biosynthesis in plants under environmental stresses. These findings also can be used in plant breeding programs for stress tolerance in sweet basil and other plants.

\section{Declarations}

\section{Compliance with ethical standards}

Conflict of interest: The authors have no conflicts of interest to declare.

\section{References}

Achnine L, Blancaflor EB, Rasmussen S, Dixon RA (2004) Colocalization of L-phenylalanine ammonialyase and cinnamate 4-hydroxylase for metabolic channeling in phenylpropanoid biosynthesis. The Plant Cell 16 (11):3098-3109

Andersen JR, Zein I, Wenzel G, Darnhofer B, Eder J, Ouzunova M, Lübberstedt T (2008) Characterization of phenylpropanoid pathway genes within European maize (Zea mays L.) inbreds. BMC Plant Biology 8 $(1): 2$

Batard Y, Schalk M, Pierrel M-A, Zimmerlin A, Durst F, Werck-Reichhart D (1997) Regulation of the cinnamate 4-hydroxylase (CYP73A1) in Jerusalem artichoke tubers in response to wounding and chemical treatments. Plant physiology 113 (3):951-959

Beatovic D, Krstic-Milosevic D, Trifunovic S, Siljegovic J, Glamoclija J, Ristic M, Jelacic S (2015) Chemical composition, antioxidant and antimicrobial activities of the essential oils of twelve Ocimum basilicum L. cultivars grown in Serbia. Records of Natural Products 9 (1):62

Belhassen E (1997) Drought tolerance in higher plants: genetical, physiological and molecular biological analysis. Springer,

Bellés JM, López-Gresa MP, Fayos J, Pallás V, Rodrigo I, Conejero V (2008) Induction of cinnamate 4hydroxylase and phenylpropanoids in virus-infected cucumber and melon plants. Plant Science 174 (5):524-533

Bilal A, Jahan N, Ahmed A, Bilal SN, Habib S, Hajra S (2012) Phytochemical and pharmacological studies on Ocimum basilicum Linn-A review. International Journal of Current Research and Review 4 (23)

Chang X, Alderson P, Wright C (2005) Effect of temperature integration on the growth and volatile oil content of basil (Ocimum basilicum L.). The Journal of Horticultural Science and Biotechnology 80 
(5):593-598

Chen A-H, Chai Y-R, Li J-N, Chen L (2007) Molecular cloning of two genes encoding cinnamate 4hydroxylase (C4H) from oilseed rape (Brassica napus). BMB Reports 40 (2):247-260

Deng Y, Lu S (2017) Biosynthesis and regulation of phenylpropanoids in plants. Critical reviews in plant sciences $36(4): 257-290$

Dominguez R, Holmes KC (2011) Actin structure and function.

Douglas CJ, Ehlting J, Harding SA, Joshi C, DiFazio S, Kole C (2011) Phenylpropanoid and phenolic metabolism in Populus: gene family structure and comparative and functional genomics. Genetics, genomics and breeding of poplars Enfield, NH: Science Publishers:304-326

Escobar AL, de Oliveira Silva FM, Acevedo P, Nunes-Nesi A, Alberdi M, Reyes-Díaz M (2017) Different levels of UV-B resistance in Vaccinium corymbosum cultivars reveal distinct backgrounds of phenylpropanoid metabolites. Plant Physiology and Biochemistry 118:541-550

Finn RD, Coggill P, Eberhardt RY, Eddy SR, Mistry J, Mitchell AL, Potter SC, Punta M, Qureshi M, SangradorVegas A (2016) The Pfam protein families database: towards a more sustainable future. Nucleic acids research 44 (D1):D279-D285

Frank MR, Deyneka JM, Schuler MA (1996) Cloning of wound-induced cytochrome P450 monooxygenases expressed in pea. Plant physiology 110 (3):1035-1046

Gang DR, Lavid N, Zubieta C, Chen F, Beuerle T, Lewinsohn E, Noel JP, Pichersky E (2002) Characterization of phenylpropene 0-methyltransferases from sweet basil: facile change of substrate specificity and convergent evolution within a plant 0-methyltransferase family. The Plant Cell 14 (2):505-519

García-Calderón M, Pons-Ferrer T, Mrazova A, Pal'ove-Balang P, Vilkova M, Pérez-Delgado CM, Vega JM, Eliašová A, Repčák M, Márquez AJ (2015) Modulation of phenolic metabolism under stress conditions in a Lotus japonicus mutant lacking plastidic glutamine synthetase. Frontiers in plant science 6:760

Gasteiger E, Hoogland C, Gattiker A, Duvaud Se, Wilkins MR, Appel RD, Bairoch A (2005) Protein identification and analysis tools on the ExPASy server. Springer,

Grayer RJ, Kite GC, Goldstone FJ, Bryan SE, Paton A, Putievsky E (1996) Infraspecific taxonomy and essential oil chemotypes in sweet basil, Ocimum basilicum. Phytochemistry 43 (5):1033-1039

Gunning PW, Ghoshdastider U, Whitaker S, Popp D, Robinson RC (2015) The evolution of compositionally and functionally distinct actin filaments. Journal of cell science 128 (11):2009-2019

Hamberger B, Hahlbrock K (2004) The 4-coumarate: CoA ligase gene family in Arabidopsis thaliana comprises one rare, sinapate-activating and three commonly occurring isoenzymes. Proceedings of the 
National Academy of Sciences 101 (7):2209-2214

Haslam E (2014) The shikimate pathway: biosynthesis of natural products series. Elsevier,

Herrmann KM, Weaver LM (1999) The shikimate pathway. Annual review of plant biology 50 (1):473-503

Hu W-J, Kawaoka A, Tsai C-J, Lung J, Osakabe K, Ebinuma H, Chiang VL (1998) Compartmentalized expression of two structurally and functionally distinct 4-coumarate: CoA ligase genes in aspen (Populus tremuloides). Proceedings of the National Academy of Sciences 95 (9):5407-5412

Huang H, Ullah F, Zhou D-X, Yi M, Zhao Y (2019) Mechanisms of ROS regulation of plant development and stress responses. Frontiers in Plant Science 10

Jenks MA, Hasegawa PM (2005) Plant abiotic stress. Wiley Online Library,

Johnson M, Zaretskaya I, Raytselis Y, Merezhuk Y, McGinnis S, Madden TL (2008) NCBI BLAST: a better web interface. Nucleic acids research 36 (suppl_2):W5-W9

Jones P, Binns D, Chang H-Y, Fraser M, Li W, McAnulla C, McWilliam H, Maslen J, Mitchell A, Nuka G (2014) InterProScan 5: genome-scale protein function classification. Bioinformatics 30 (9):1236-1240

Joshi RK (2014) Chemical composition and antimicrobial activity of the essential oil of Ocimum basilicum L.(sweet basil) from Western Ghats of North West Karnataka, India. Ancient science of life 33 (3):151

Kelley LA, Mezulis S, Yates CM, Wass MN, Sternberg MJ (2015) The Phyre2 web portal for protein modeling, prediction and analysis. Nature protocols 10 (6):845

Khair-ul-Bariyah S, Ahmed D, Ikram M (2012) Ocimum basilicum: a review on phytochemical and pharmacological studies. Pak J Chem 2 (2):78-85

Khakdan F, Alizadeh H, Ranjbar M (2018) Molecular cloning, functional characterization and expression of a drought inducible phenylalanine ammonia-lyase gene (ObPAL) from Ocimum basilicum L. Plant Physiology and Biochemistry 130:464-472

Khakdan F, Nasiri J, Ranjbar M, Alizadeh H (2017) Water deficit stress fluctuates expression profiles of $4 \mathrm{Cl}, \mathrm{C} 3 \mathrm{H}, \mathrm{COMT}, \mathrm{CVOMT}$ and EOMT genes involved in the biosynthetic pathway of volatile phenylpropanoids alongside accumulation of methylchavicol and methyleugenol in different Iranian cultivars of basil. Journal of plant physiology 218:74-83

Kim J, Choi B, Natarajan S, Bae H (2013) Expression analysis of kenaf cinnamate 4-hydroxylase (C4H) ortholog during developmental and stress responses.

Kim YS, Kim YB, Kim Y, Lee MY, Park SU (2014) Overexpression of cinnamate 4-hydroxylase and 4coumaroyl CoA ligase prompted flavone accumulation in Scutellaria baicalensis hairy roots. Natural 
product communications 9 (6):1934578X1400900618

Koopmann E, Logemann E, Hahlbrock K (1999) Regulation and functional expression of cinnamate 4hydroxylase from parsley. Plant physiology 119 (1):49-56

Korkina L (2007) Phenylpropanoids as naturally occurring antioxidants: from plant defense to human health. Cell Mol Biol 53 (1):15-25

Lavhale SG, Kalunke RM, Giri AP (2018) Structural, functional and evolutionary diversity of 4-coumarateCoA ligase in plants. Planta 248 (5):1063-1078

Leng X, Jia H, Sun X, Shangguan L, Mu Q, Wang B, Fang J (2015) Comparative transcriptome analysis of grapevine in response to copper stress. Scientific reports 5:17749

Li X, Kim JK, Park SU (2019) Molecular cloning and characterization of rosmarinic acid biosynthetic genes and rosmarinic acid accumulation in Ocimum basilicum L. Saudi journal of biological sciences 26 (3):469-472

Lim TK (2012) Edible medicinal and non-medicinal plants, vol 1. Springer,

Livak KJ, Schmittgen TD (2001) Analysis of relative gene expression data using real-time quantitative PCR and the 2- $\triangle \triangle C T$ method. methods 25 (4):402-408

Mandoulakani BA, Eyvazpour E, Ghadimzadeh M (2017) The effect of drought stress on the expression of key genes involved in the biosynthesis of phenylpropanoids and essential oil components in basil (Ocimum basilicum L.). Phytochemistry 139:1-7

Marchler-Bauer A, Derbyshire MK, Gonzales NR, Lu S, Chitsaz F, Geer LY, Geer RC, He J, Gwadz M, Hurwitz DI (2014) CDD: NCBI's conserved domain database. Nucleic acids research 43 (D1):D222-D226

McGuffin LJ, Bryson K, Jones DT (2000) The PSIPRED protein structure prediction server. Bioinformatics 16 (4):404-405

Meek CR Arthropod Population, Phenylalanine Ammonia Lyase Activity, and Fresh Weight of Sweet Basil (Ocimum basilicum) as Affected by Plant Age and Bacillus thuringiensis Treatment. In: Proceedings of the Oklahoma Academy of Science, 2015. pp 9-17

Miraj S, Kiani S (2016) Study of pharmacological effect of Ocimum basilicum: A review. Der Pharmacia Lettre 8 (9):276-280

Moura JCMS, Bonine CAV, de Oliveira Fernandes Viana J, Dornelas MC, Mazzafera P (2010) Abiotic and biotic stresses and changes in the lignin content and composition in plants. Journal of integrative plant biology $52(4): 360-376$ 
Nerio LS, Olivero-Verbel J, Stashenko E (2010) Repellent activity of essential oils: a review. Bioresource technology 101 (1):372-378

Niinemets Ü, Kännaste A, Copolovici L (2013) Quantitative patterns between plant volatile emissions induced by biotic stresses and the degree of damage. Frontiers in Plant Science 4:262

Park NI, Park JH, Park SU (2012) Overexpression of cinnamate 4-hydroxylase gene enhances biosynthesis of decursinol angelate in Angelica gigas hairy roots. Molecular biotechnology 50 (2):114120

Pereira A (2016) Plant abiotic stress challenges from the changing environment. Frontiers in plant science 7:1123

Perin EC, da Silva Messias R, Borowski JM, Crizel RL, Schott IB, Carvalho IR, Rombaldi CV, Galli V (2019) ABA-dependent salt and drought stress improve strawberry fruit quality. Food chemistry 271:516-526

Petersen TN, Brunak S, von Heijne G, Nielsen H (2011) SignalP 4.0: discriminating signal peptides from transmembrane regions. Nature methods 8 (10):785-786

Pinasseau L, Vallverdú-Queralt A, Verbaere A, Roques M, Meudec E, Le Cunff L, Péros J-P, Ageorges A, Sommerer N, Boulet J-C (2017) Cultivar diversity of grape skin polyphenol composition and changes in response to drought investigated by LC-MS based metabolomics. Frontiers in plant science 8:1826

Purushothaman B, PrasannaSrinivasan R, Suganthi P, Ranganathan B, Gimbun J, Shanmugam K (2018) A comprehensive review on Ocimum basilicum. Journal of Natural Remedies 18 (3):71-85

Rastogi S, Shah S, Kumar R, Vashisth D, Akhtar MQ, Kumar A, Dwivedi UN, Shasany AK (2019) Ocimum metabolomics in response to abiotic stresses: Cold, flood, drought and salinity. PloS one 14 (2):e0210903

Reddy MS, Chen F, Shadle G, Jackson L, Aljoe H, Dixon RA (2005) Targeted down-regulation of cytochrome P450 enzymes for forage quality improvement in alfalfa (Medicago sativa L.). Proceedings of the National Academy of Sciences 102 (46):16573-16578

Rezaie R, Mandoulakani BA, Fattahi M (2020) Cold stress changes antioxidant defense system, phenylpropanoid contents and expression of genes involved in their biosynthesis in Ocimum basilicum $\mathrm{L}$. Scientific reports $10(1): 1-10$

Rossi L, Borghi M, Francini A, Lin X, Xie D-Y, Sebastiani L (2016) Salt stress induces differential regulation of the phenylpropanoid pathway in Olea europaea cultivars Frantoio (salt-tolerant) and Leccino (saltsensitive). Journal of plant physiology 204:8-15

Sadeghi M, Dehghan S, Fischer R, Wenzel U, Vilcinskas A, Kavousi HR, Rahnamaeian M (2013) Isolation and characterization of isochorismate synthase and cinnamate 4-hydroxylase during salinity stress, wounding, and salicylic acid treatment in Carthamus tinctorius. Plant signaling \& behavior 8 (11):e27335 
Saxena M, Saxena J, Nema R, Singh D, Gupta A (2013) Phytochemistry of medicinal plants. Journal of pharmacognosy and phytochemistry 1 (6)

Sharma A, Shahzad B, Rehman A, Bhardwaj R, Landi M, Zheng B (2019) Response of phenylpropanoid pathway and the role of polyphenols in plants under abiotic stress. Molecules 24 (13):2452

Silva RRd, da Câmara CA, Almeida AV, Ramos CS (2012) Biotic and abiotic stress-induced phenylpropanoids in leaves of the mango (Mangifera indica L., Anacardiaceae). Journal of the Brazilian Chemical Society 23 (2):206-211

Simon JE, Quinn J, Murray RG (1990) Basil: a source of essential oils. Advances in new crops:484-489

Solecka D (1997) Role of phenylpropanoid compounds in plant responses to different stress factors. Acta Physiologiae Plantarum 19 (3):257-268

Soltani BM, Ehlting J, Hamberger B, Douglas CJ (2006) Multiple cis-regulatory elements regulate distinct and complex patterns of developmental and wound-induced expression of Arabidopsis thaliana $4 \mathrm{CL}$ gene family members. Planta 224 (5):1226-1238

Swedan E (2013) PAL gene activity and total phenolic compounds in some members of lamiaceae. Journal of Applied Sciences Research 9 (2):1222-1227

Tahsili J, Sharifi M, Behmanesh M, Pourbozorgi-Rudsari N, Ziaei M (2012) Expression of 4 genes in Ocimum basilicum and their relationship with phenylpropanoids content.

Van Wyk B-E, Wink M (2018) Medicinal plants of the world. CABI,

Wang C-H, Yu J, Cai Y-X, Zhu P-P, Liu C-Y, Zhao A-C, Lü R-H, Li M-J, Xu F-X, Yu M-D (2016) Characterization and functional analysis of 4-coumarate: CoA ligase genes in mulberry. PloS one 11 (5):e0155814

Wang L, Shan T, Xie B, Ling C, Shao S, Jin P, Zheng Y (2019) Glycine betaine reduces chilling injury in peach fruit by enhancing phenolic and sugar metabolisms. Food chemistry 272:530-538

Winkel-Shirley B (1999) Evidence for enzyme complexes in the phenylpropanoid and flavonoid pathways. Physiologia Plantarum 107 (1):142-149

Xu B, Escamilla-Treviño LL, Sathitsuksanoh N, Shen Z, Shen H, Percival Zhang YH, Dixon RA, Zhao B (2011) Silencing of 4-coumarate: coenzyme A ligase in switchgrass leads to reduced lignin content and improved fermentable sugar yields for biofuel production. New phytologist 192 (3):611-625

Xu Z, Zhang D, Hu J, Zhou X, Ye X, Reichel KL, Stewart NR, Syrenne RD, Yang X, Gao P Comparative genome analysis of lignin biosynthesis gene families across the plant kingdom. In: BMC bioinformatics, 2009. vol 11. BioMed Central, p S3 
Yang L, Wang C, Guo W, Li X, Lu M, Yu C (2006) Differential expression of cell wall related genes in the elongation zone of rice roots under water deficit. Russian Journal of Plant Physiology 53 (3):390-395

Yoshimura K, Masuda A, Kuwano M, Yokota A, Akashi K (2008) Programmed proteome response for drought avoidance/tolerance in the root of a C3 xerophyte (wild watermelon) under water deficits. Plant and Cell Physiology 49 (2):226-241

Yu C-S, Cheng C-W, Su W-C, Chang K-C, Huang S-W, Hwang J-K, Lu C-H (2014) CELLO2GO: a web server for protein subCELlular LOcalization prediction with functional gene ontology annotation. PLoS One 9 (6):e99368

\section{Tables}

Table 1. Primers used for the molecular cloning and gene expression analysis.

\begin{tabular}{|c|c|c|c|c|}
\hline Primer name & Sequence (5口"3ם) & $\begin{array}{l}\text { Product } \\
\text { Length } \\
\text { (bp) }\end{array}$ & $\begin{array}{l}\mathrm{Ta} \\
\left({ }^{\circ} \mathrm{C}\right)\end{array}$ & \multirow{9}{*}{$\begin{array}{l}\text { Molecular } \\
\text { Cloning }\end{array}$} \\
\hline Full-4CL-F & ССТТСТТССТСТТТСТТСТТС & 1,815 & 60 & \\
\hline Full- $4 C L-\mathrm{R}$ & ATGAACAAGGTAGGATAAATGG & & & \\
\hline $\begin{array}{l}\text { Full-CVOMT- } \\
\text { F }\end{array}$ & AGTTCACCATATAAATTACATCCA & 1,214 & 60 & \\
\hline $\begin{array}{l}\text { Full-CVOMT- } \\
\text { R }\end{array}$ & AAGTATTCGTTGCCTTTACATA & & & \\
\hline Full- $C 4 H-\mathrm{F}$ & CACCGAAAATGGATCTTCTC & 1,631 & 59 & \\
\hline Full- $C 4 H-\mathrm{R}$ & CCAATACCAACACTACAACAT & & & \\
\hline $\begin{array}{l}\text { Full-ACTIN- } \\
\mathrm{F}\end{array}$ & СТCTTCCGATCTCTCTCTTAA & 1,334 & 61 & \\
\hline $\begin{array}{l}\text { Full- } A C T I N- \\
\mathrm{R}\end{array}$ & CATCAGAAATCACTTCATAGACT & & & \\
\hline $4 C L-\mathrm{F}$ & CGACTGCGAGAACCATAG & 100 & 53 & \multirow{8}{*}{$\begin{array}{c}\text { Gene } \\
\text { Expression } \\
\text { Study }\end{array}$} \\
\hline $4 C L-\mathrm{R}$ & TCCTTCACCCTGTCTACG & & & \\
\hline CVOMT-F & GGGAGAAGTTAGCAAATAAGC & 163 & 52 & \\
\hline CVOMT-R & TTAGCCATCGTTCCATTACC & & & \\
\hline$C 4 H-F$ & AATCTCCACGACGCCAAG & 151 & 57 & \\
\hline$C 4 H-\mathrm{R}$ & CGACTTTAGCCTCCTCTTCC & & & \\
\hline$A C T I N-\mathrm{F}$ & GACAACATACAACTCCATCAT & 126 & 58 & \\
\hline$A C T I N-\mathrm{R}$ & GTTATCTCСTTGCTCATTCTG & & & \\
\hline
\end{tabular}

Table 2. The features of identified genes. 
Gene Name cDNA length ORF length Protein Length (aa) MolecularWeight (bp) (bp) (kDa)

\begin{tabular}{ccccc}
\hline $4 C L$ & 1,815 & 1,704 & 567 & 61.12 \\
CVOMT & 1,214 & 1,071 & 356 & 39.922 \\
C4H & 1,631 & 1,518 & 505 & 58.044 \\
ACTIN & 1,334 & 1,134 & 377 & 41.664 \\
\hline
\end{tabular}

Table 3. Functional characterization of identified genes.

\begin{tabular}{lcccc}
\hline $\begin{array}{c}\text { Gene } \\
\text { Name }\end{array}$ & $\begin{array}{c}\text { Signal } \\
\text { sequence }\end{array}$ & $\begin{array}{c}\text { Localization } \\
\text { site }\end{array}$ & $\begin{array}{c}\text { Secondary } \\
\text { structures }\end{array}$ & $\begin{array}{c}\text { Functional } \\
\text { domain }\end{array}$ \\
\hline $4 C L$ & No & Cytoplasmic & $41 \% \alpha$ and $21 \%$ & 4-coumarate-CoA ligase \\
$C V O M T$ & No & Cytoplasmic & $\begin{array}{c}56 \% \alpha \text { and } 13 \% \\
\beta\end{array}$ & $\begin{array}{c}\text { AdoMet-MTase/ Dimerization } \\
\text { domain }\end{array}$ \\
$C 4 H$ & No & Cytoplasmic & $\begin{array}{c}64 \% \alpha \text { and } 8 \% \\
\beta\end{array}$ & $\begin{array}{c}\text { Tans-cinnamate 4- } \\
\text { monooxygenase }\end{array}$ \\
ACTIN & No & Cytoplasmic & $\begin{array}{c}38 \% \alpha \text { and } 23 \% \\
\beta\end{array}$ & NBD_sugar-kinase_HSP70 \\
\hline
\end{tabular}

\section{Figures}

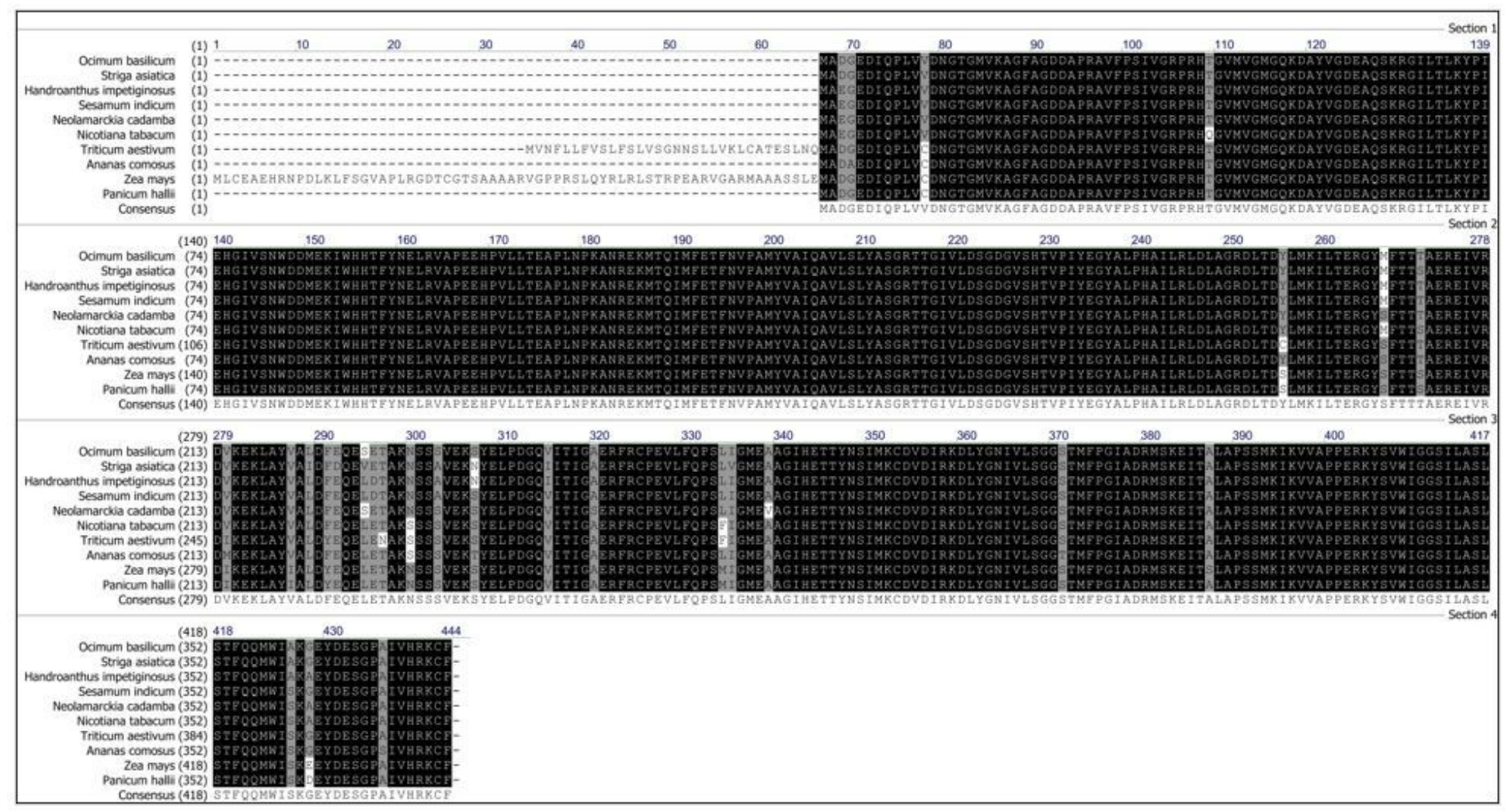


Figure 1

Multiple sequence alignment of identified ACTIN of O. basilicum with its orthologs in other mono- and dicotyledon plant species. The black and grey colors show identical and conservative amino acids, respectively. The numbers above the alignment display the position of amino acids. Gaps (-) were inserted to improve the alignment.

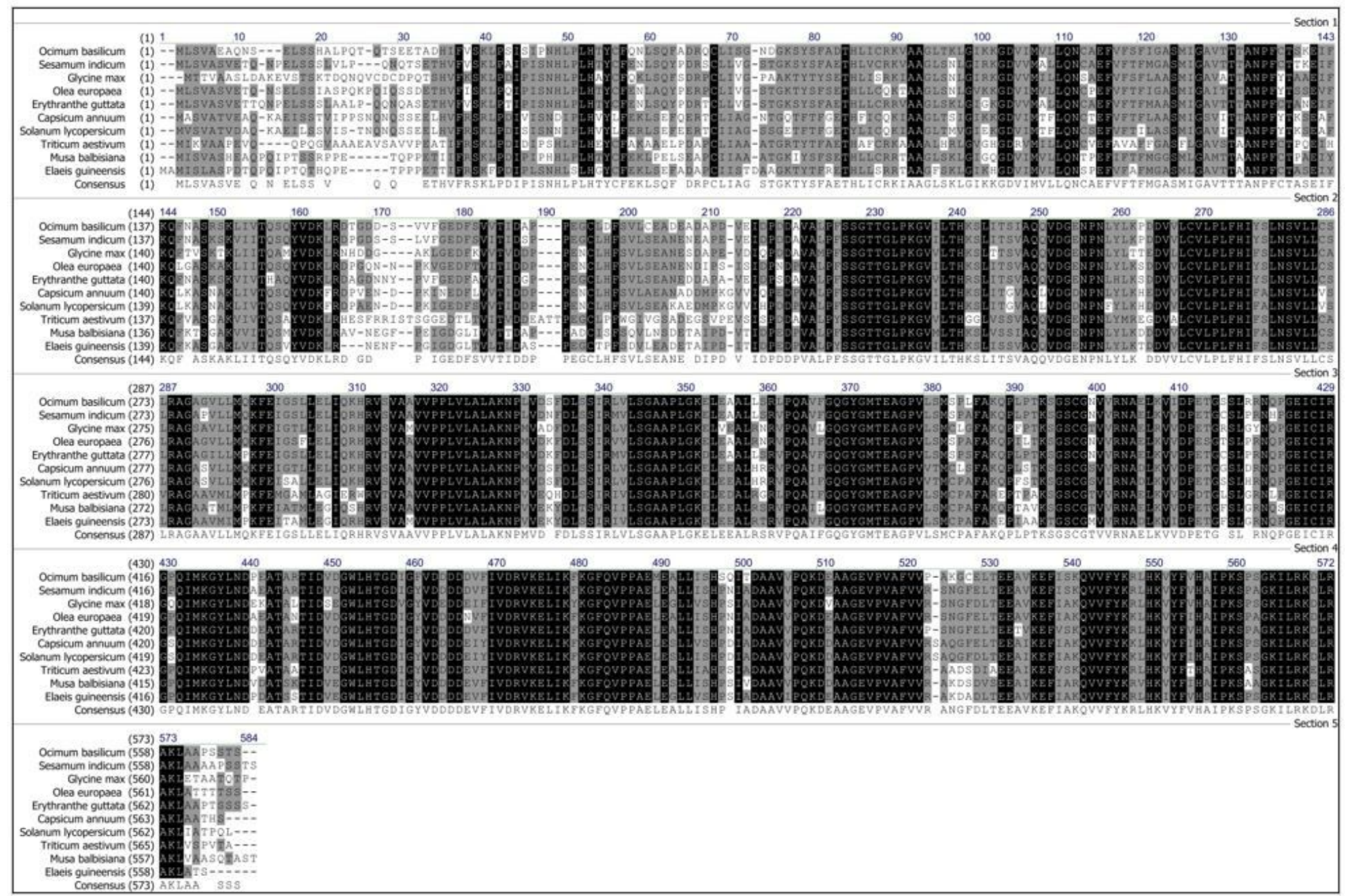

Figure 2

Multiple sequence alignment of identified $4 \mathrm{CL}$ of $\mathrm{O}$. basilicum with its orthologs in other mono- and dicotyledon plant species. The black and grey colors show identical and conservative amino acids, respectively. The numbers above the alignment display the position of amino acids. Gaps (-) were inserted to improve the alignment. 


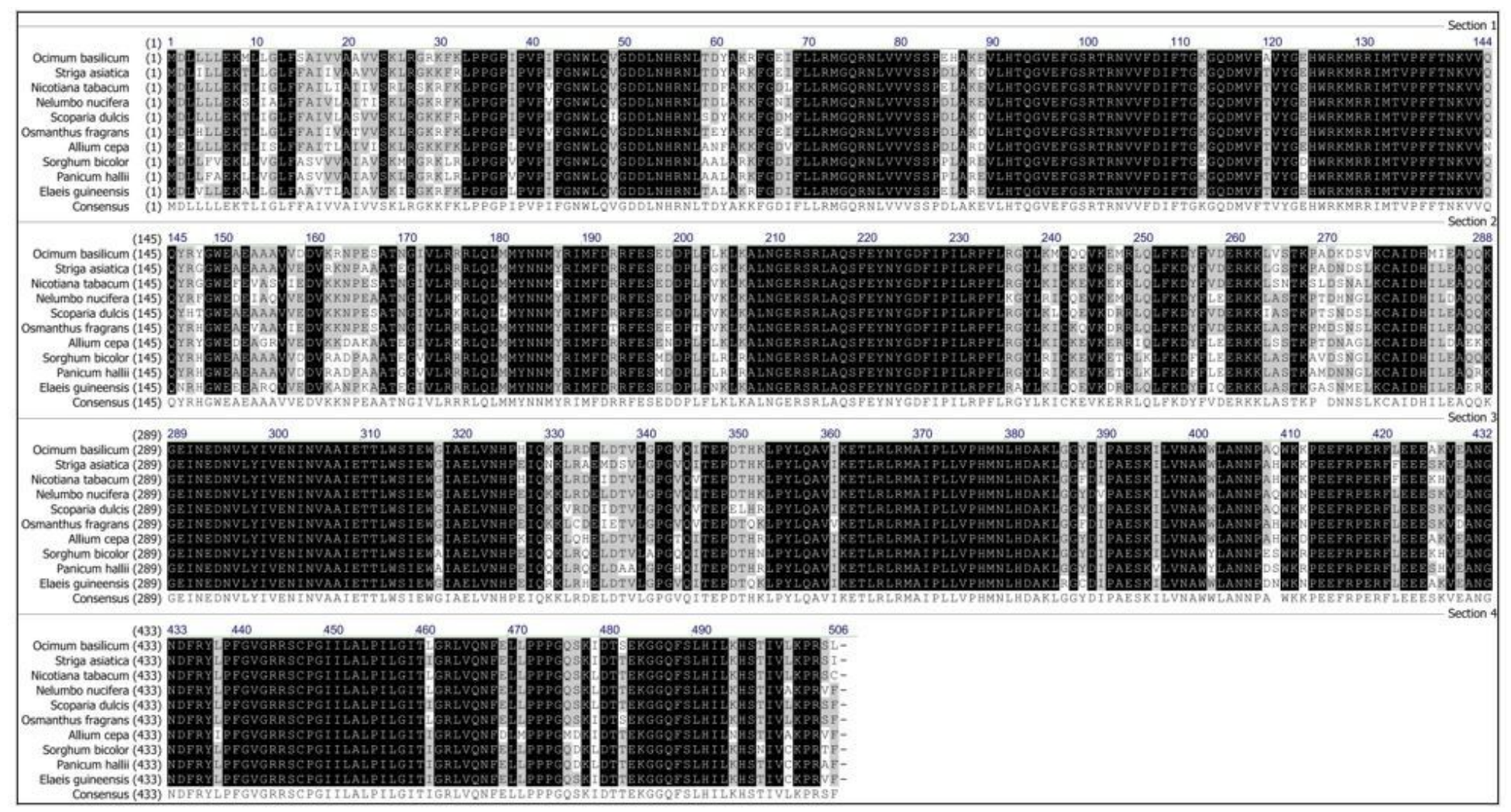

Figure 3

Multiple sequence alignment of identified $\mathrm{C} 4 \mathrm{H}$ of $\mathrm{O}$. basilicum with its orthologs in other mono- and dicotyledon plant species. The black and grey colors show identical and conservative amino acids, respectively. The numbers above the alignment display the position of amino acids.

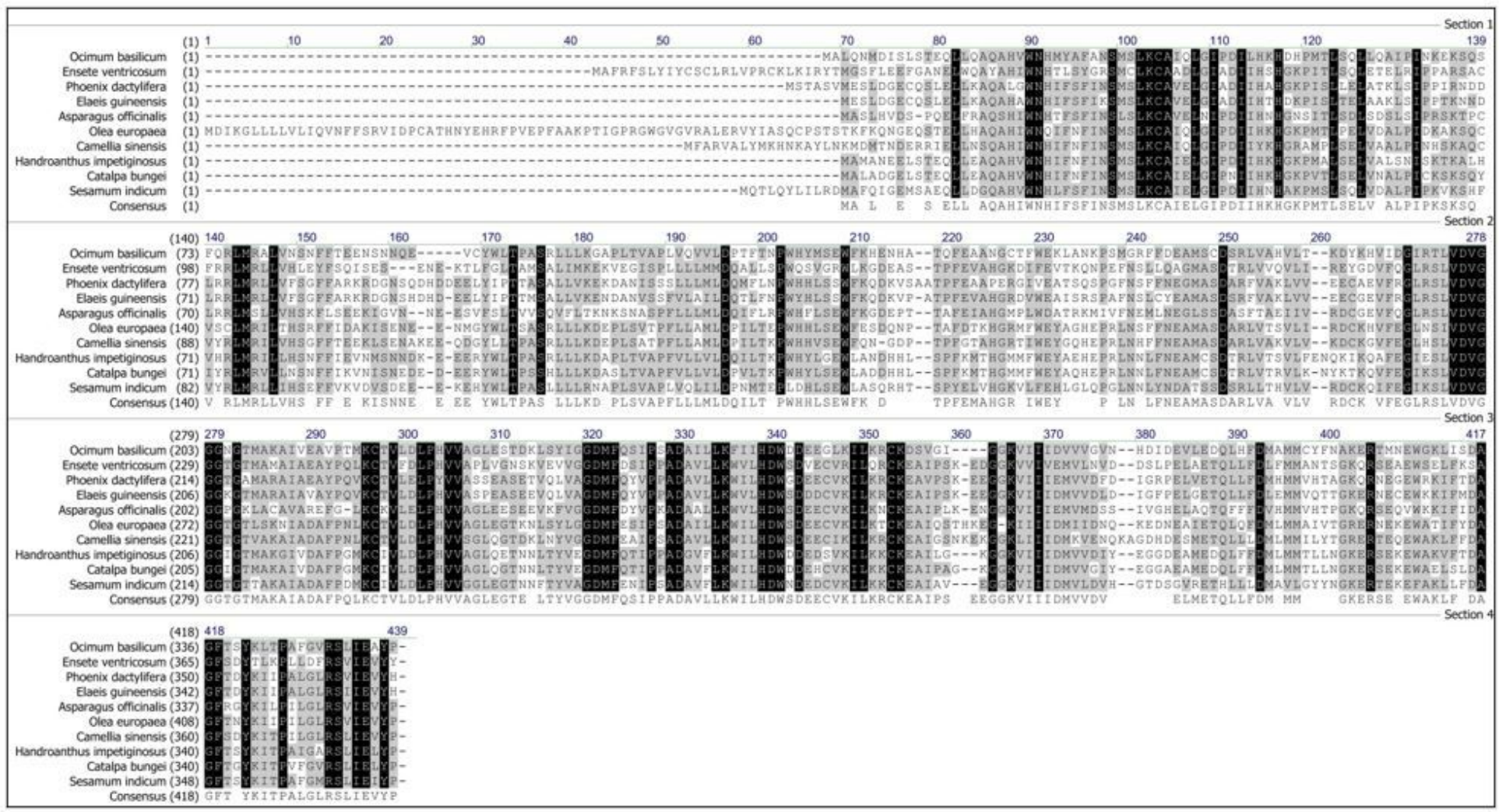


Figure 4

Multiple sequence alignment of identified CVOMT of 0 . basilicum with its orthologs in other mono- and dicotyledon plant species. The black and grey colors show identical and conservative amino acids, respectively. The numbers above the alignment display the position of amino acids. Gaps (-) were inserted to improve the alignment.

$4 \mathrm{CL}$

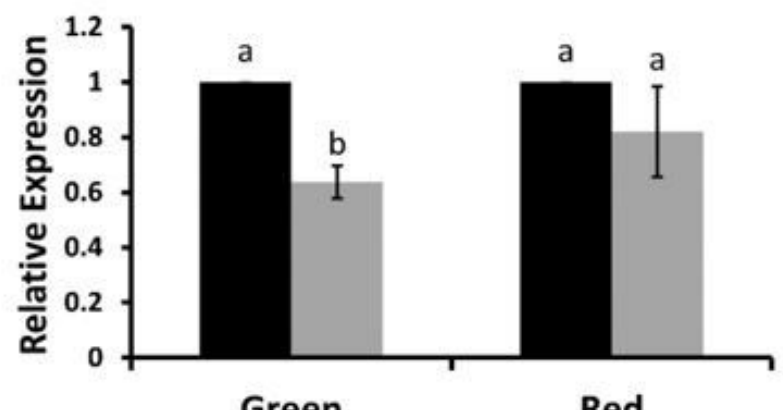

$4 \mathrm{CL}$

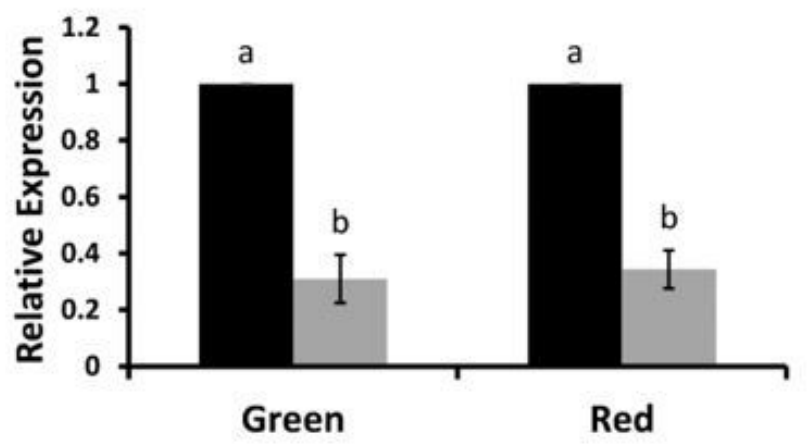

$4 \mathrm{CL}$

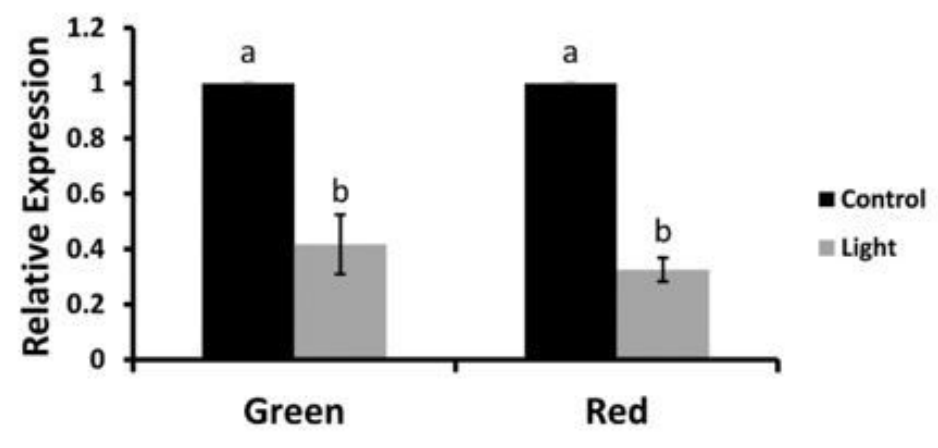

$4 C L$
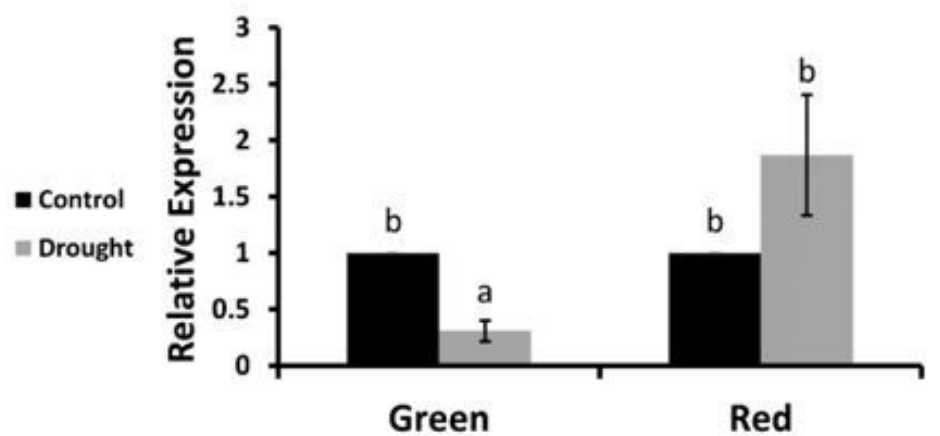

$4 \mathrm{CL}$
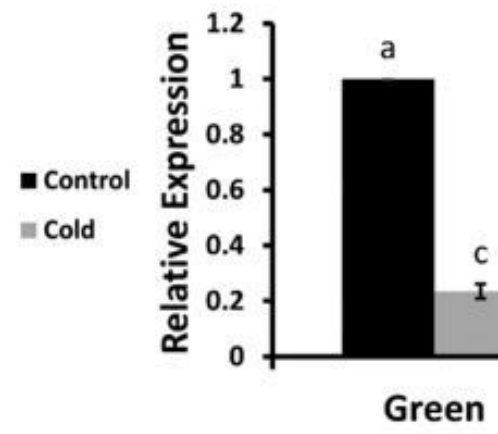

\section{Figure 5}

Expression pattern of $4 \mathrm{CL}$ gene in red and green cultivars of basil under different abiotic stresses. Bars show standard errors. Letters above the error show significant differences. Means with the same letter are not significantly different. The Tukey's test was used for multiple comparisons of means at $P<0.05$. 
$\mathrm{C} 4 \mathrm{H}$

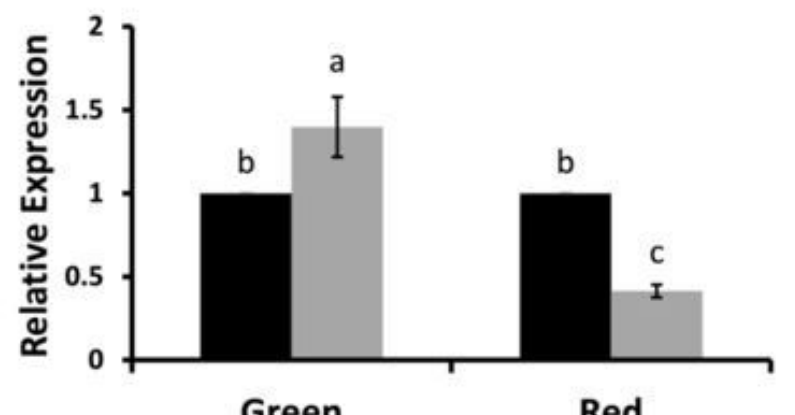

$\mathrm{C} 4 \mathrm{H}$
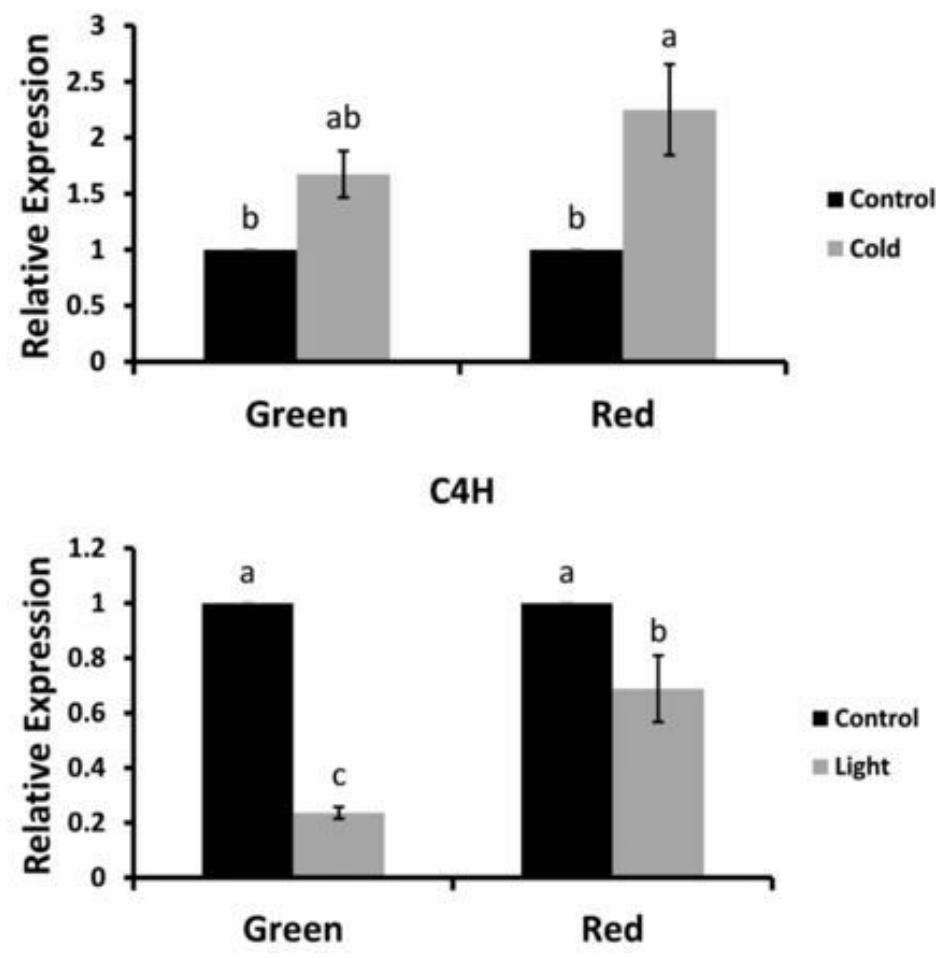

$\mathrm{C} 4 \mathrm{H}$

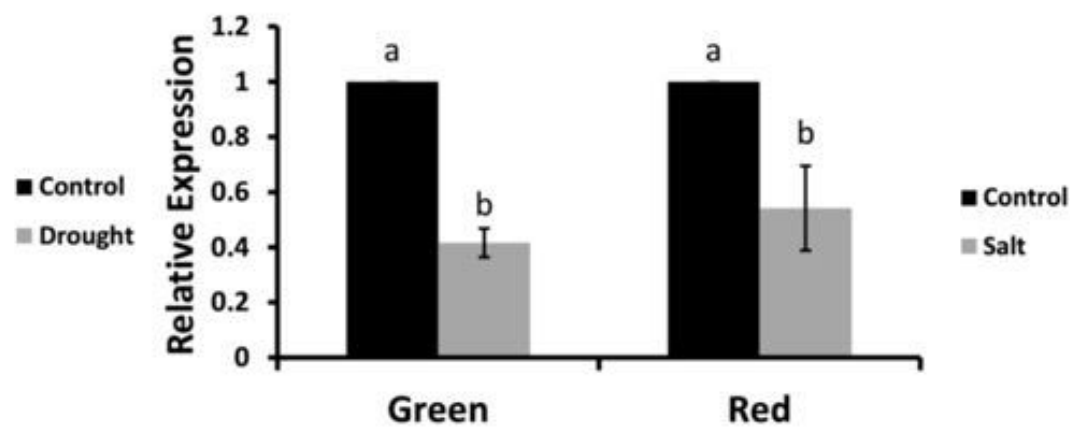

$\mathrm{C} 4 \mathrm{H}$

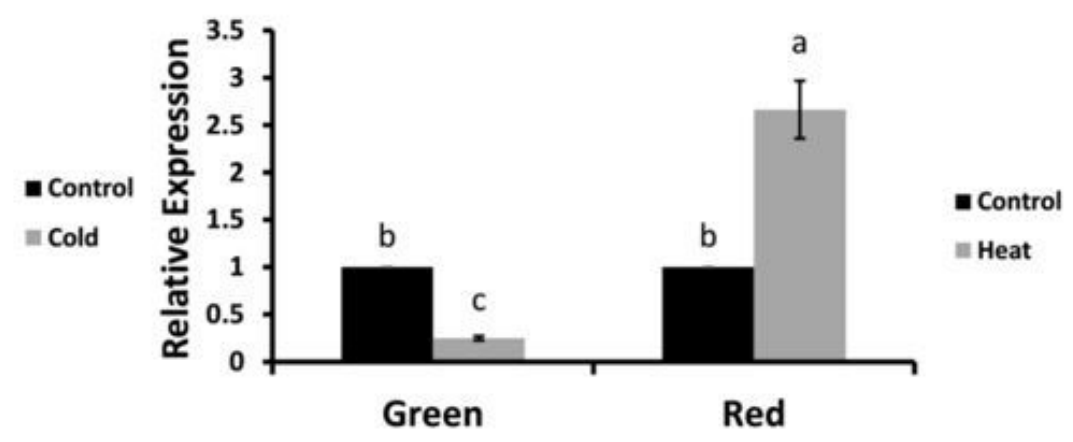

Figure 6

Expression pattern of $\mathrm{C} 4 \mathrm{H}$ gene in red and green cultivars of basil under different abiotic stresses. Bars show standard errors. Letters above the error show significant differences. Means with the same letter are not significantly different. The Tukey's test was used for multiple comparisons of means at $P<0.05$. 
CVOMT

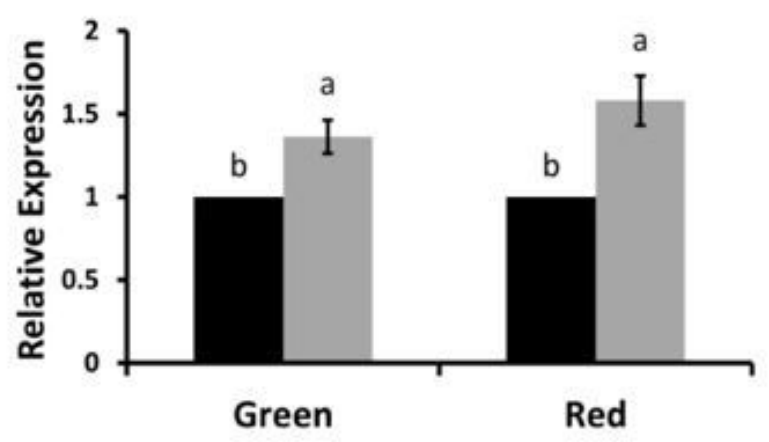

CVOMT

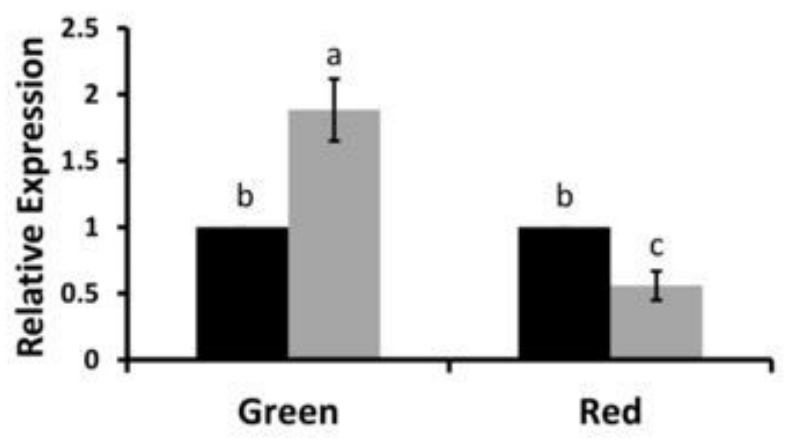

CVOMT

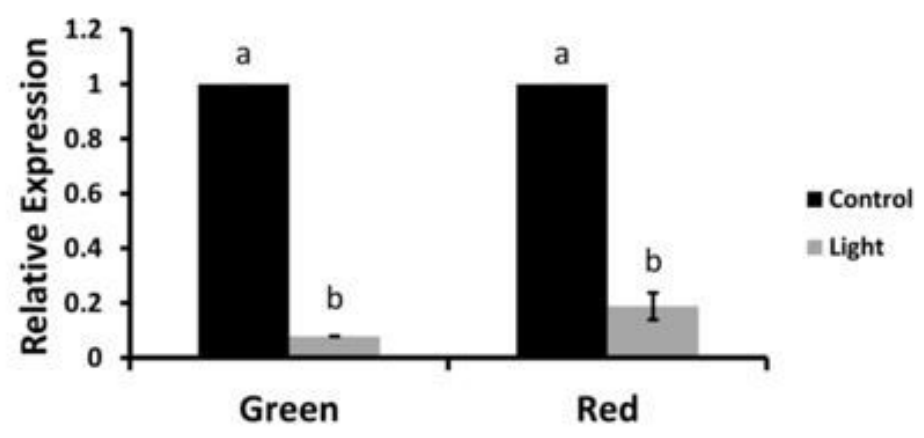

CVOMT

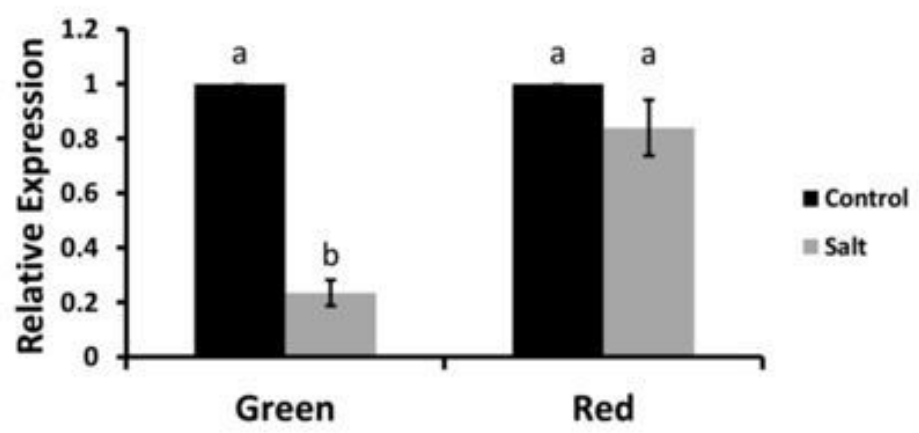

CVOMT

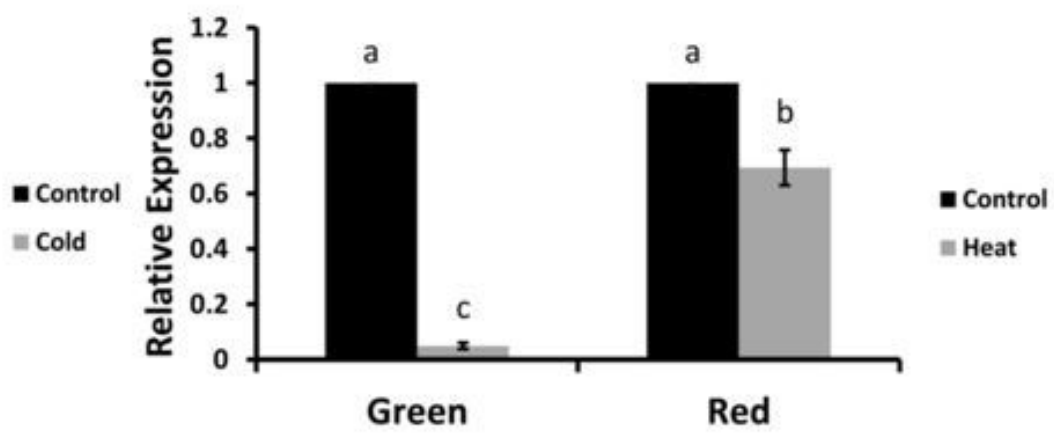

Green

Red

\section{Figure 7}

Expression pattern of CVOMT gene in red and green cultivars of basil under different abiotic stresses. Bars show standard errors. Letters above the error show significant differences. Means with the same letter are not significantly different. The Tukey's test was used for multiple comparisons of means at $\mathrm{P}<$ 0.05 .

\section{Supplementary Files}

This is a list of supplementary files associated with this preprint. Click to download.

- Keygenesinthephenylpropanoids....blin.rar

- Supplementary.docx 